\title{
PENGARUH BIMBINGAN TEMAN SEBAYA TERHADAP KEMAMPUAN KOMUNIKASI INTERPERSONAL PESERTA DIDIK KELAS XI IPS DI SMAN 7 KOTA KEDIRI TAHUN AJARAN 2018/2019
}

\author{
Novilia Ega Primasari ${ }^{1}$, Setya Adi Sancaya ${ }^{2}$, Nora Yuniar Setyaputri ${ }^{3}$ \\ SMA Negeri 7 Kediri ${ }^{1}$ \\ Universitas Nusantara PGRI Kediri2,3 \\ primasariega@gmail.com 1 , sadisancaya@gmail.com ${ }^{2}$, setyaputrinora@gmail.com³
}

\begin{abstract}
ABSTRAK
Penelitian ini berdasarkan dari hasil praktek kerja lapangan peneliti, bahwa kemampuan komunikasi peserta didik kelas XI IPS di SMAN 7 Kota Kediri rendah. Rumusan masalah yang diambil adalah "Adakah pengaruh pemberian bimbingan teman sebaya terhadap kemampuan komunikasi interpersonal peserta didik kelas XI IPS di SMAN 7 kota kediri tahun ajaran 2018/2019?". Penelitian ini merupakan penelitian kuantitatif dengan menggunakan metode pre experimental design. Populasi dalam penelitian ini adalah seluruh peserta didik kelas XI IPS SMAN 7 Kota Kediri sebanyak 134 peserta didik, dengan sampel penelitian kelas XI IPS 1 sebanyak 5 peserta didik, kelas XI IPS 2 sebanyak 3 peserta didik kelas XI IPS 3 sebanyak 4 peserta didik, kelas XI IPS 4 sebanyak 7 peserta didik dan kelas XI IPS 5 sebanyak 3 peserta didik. Metode pengumpulan data dalam penelitian ini adalah skala kemampuan komunikasi interpersonal. Hasil uji reliabilitas menggunakan Alpha Cronbach yakni sebesar 0,788. Penelitian ini menggunakan independent sample t-test untuk mengetahui pengaruh bimbingan teman sebaya terhadap kemampuan komunikasi interpersonal peserta didik. Berdasarkan hasil uji independent sample $t$-test diperoleh $\mathrm{t}$ hitung lebih besar dari t tabel yaitu $34,799>2,080$ pada taraf signifikansi $5 \%$. Maka $\mathrm{H}_{0}$ ditolak dan $\mathrm{Ha}_{\mathrm{a}}$ diterima, artinya bahwa bimbingan teman sebaya berpengaruh untuk meningkatkan kemampuan komunikasi interpersonal peserta didik kelas XI IPS di SMAN 7 Kota Kediri.
\end{abstract}

Kata Kunci bimbingan teman sebaya, kemampuan komunikasi interpersonal

Cara mengutip: Primasari, N. E., Sancaya, S. A., Setyaputri N. Y. (2018) Pengaruh Bimbingan Teman Sebaya Terhadap Kemampuan Komunikasi Interpersonal Peserta Didik Kelas XI IPS di SMAN 7 Kota Kediri Tahun Ajaran 2018/2019. Jurnal Nusantara of Research, 5(2), 67-71.

\section{PENDAHULUAN}

Masalah pendidikan selalu memiliki hubungan yang berkesinambungan dengan perkembangan suatu bangsa. Pendidikan adalah usaha sadar dan terencana untuk mewujudkan peserta didik yang mampu berpikir secara normal, mengembangkan potensi yang dimilikinya agar dapat tercapai tugas-tugas perkembangannya. Pendidikan adalah langkah yang paling tepat untuk mencapai tujuan dan cita-cita pribadi individu khususnya kemampuan dalam berkomunikasi. Komunikasi sangat dibutuhkan karena individu sebagai mahkluk sosial yang tidak dapat hidup sendiri sehingga dibutuhkan kemauan untuk menjalin hubungan baik dengan orang lain. Komunikasi terjadi dimana-dimana, di rumah, di sekolah, di kampus, di kantor, bahkan di tempat ibadah. 
Dalam rangka memberikan bantuan untuk meningkatkan kemampuan komunikasi interpersonal peserta didik, peneliti mencoba menggunakan pendekatan melalui salah satu teknik alternatif, yaitubimbingan teman sebaya.Menurut Iceu (2011 : 368), Teman sebaya dianggap peduli dan yang paling mengerti akan permasalahan yang di hadapi seorang individu. Teman sebaya juga dianggap sebagai sahabat dan menjadi tempat teraman dalam berbagi masalah. Mereka memiliki cara berbahasa yang sama sehingga cara penyampaian masalah tidak harus menggunakan Bahasa yang sopan dan formal.Teman sebaya merupakan faktor yang sangat berpengaruh terhadap kehidupan di usia remaja. Adapun rumusan masalah yang diambil adalah "adakah pengaruh pemberian bimbingan teman sebaya terhadap kemampuan komunikasi interpersonal peserta didik kelas XI IPS di SMAN 7 Kota Kediri tahun ajaran 2018/2019?

Dengan adanya penelitian ini diharapkan dapat bermanfaat sebagai bahan masukan dalam memperluas ilmu pengetahuan khususnya dalam ilmu pendidikan dalam bidang bimbingan dan konseling mengenai meningkatkan kemampuan komunikasi interpersonal peserta didik dengan menggunakan layanan bimbingan teman sebaya.

\section{METODE}

Kemampuan komunikasi peserta didik dapat diukur menggunakan instrumen skala psikologis. Dalam penyusunan skala komunikasi interpersonal disusun berdasarkan karakteristik komunikasi interpersonal peserta didik milik DeVinto (dalam Astiningrum, 2013), yang kemudian dimodifikasi menyesuaikan dengan tujuan penelitian.

Peneliti mengembangkan indikator kemampuan komunikasi interpersonal berdasarkan aspek- aspek komunikasi interpersonal adalah keterbukaan, empati, dukungan, rasa positif dan kesetaraan. Uji validitas dan reliabilitas instrumen dilakukan dengan melakukan ujilapangan. Semakin tinggi nilai (scoring) skala psikologis kemampuan komunikasi interpersonal peserta didik berarti semakin tinggi pula tingkat kemampuan komunikasi interpersonal peserta didik, begitu pula sebaliknya.

\section{HASIL}

Penelitian ini dilakukan pada peserta didik kelas XI IPS SMAN 7 Kota Kediri Tahun Pelajaran 2017/2018. Dalam penelitian ini, peneliti menggunakan skala kemampuan komunikasi interpersonal sebagai instrumen utama dalam pengambilan data, instrumen diberikan dalam dua tahap, yaitu sebelum (pretest) dan sesudah (posttest) subjek penelitian diberikan perlakuan (treatment) berupa bimbingan teman sebaya mengenai kemampuan komunikasi interpersonal peserta didik.

Ada pun hasil perhitungan perolehan data pretest dan posttest menggunakan instrumen angket mengenai kemampuan komunikasi seperti yang ditunjukkan pada tabel 1. terkait dengan data pretes dan pada table 2. terkait dengan data postes yang dilakukan. 
Tabel 1. Data Kemampuan Komunikasi Interpersonal Peserta didik Sebelum Bimbingan Teman Sebaya

\begin{tabular}{ccclllll}
\hline No. & Responden & Skor & Kategori & No. & Responden & Skor & Kategori \\
\hline 1. & ResA & 72 & Rendah & 12. & ResK & 72 & Rendah \\
\hline 2. & ResB & 69 & Rendah & 13. & ResL & 73 & Rendah \\
\hline 3. & ResB & 70 & Rendah & 14. & ResM & 72 & Rendah \\
\hline 4. & ResC & 70 & Rendah & 15. & ResN & 73 & Rendah \\
\hline 5. & ResD & 71 & Rendah & 16. & ResO & 72 & Rendah \\
\hline 6. & ResE & 74 & Rendah & 17. & ResP & 71 & Rendah \\
\hline 7. & ResF & 71 & Rendah & 18. & ResQ & 72 & Rendah \\
\hline 8. & ResG & 71 & Rendah & 19. & ResR & 72 & Rendah \\
\hline 9. & ResH & 72 & Rendah & 20. & ResS & 72 & Rendah \\
\hline 10. & Resl & 73 & Rendah & 21. & ResT & 73 & Rendah \\
\hline 11. & ResJ & 71 & Rendah & 22. & ResU & 73 & Rendah \\
\hline
\end{tabular}

Tabel 2. Data Kemampuan Komunikasi Interpersonal Peserta didik Setelah Bimbingan Teman Sebaya

\begin{tabular}{ccrccccc}
\hline No. & Responden & Skor & Kategori & No. & Responden & Skor & Kategori \\
\hline 1. & ResA & 100 & Tinggi & 12. & ResK & 105 & Tinggi \\
\hline 2. & ResB & 95 & Sedang & 13. & ResL & 104 & Tinggi \\
\hline 3. & ResB & 109 & Tinggi & 14. & ResM & 102 & Tinggi \\
\hline 4. & ResC & 94 & Sedang & 15. & ResN & 105 & Tinggi \\
\hline 5. & ResD & 101 & Tinggi & 16. & ResO & 113 & Tinggi \\
\hline 6. & ResE & 112 & Tinggi & 17. & ResP & 106 & Tinggi \\
\hline 7. & ResF & 104 & Tinggi & 18. & ResQ & 103 & Tinggi \\
\hline 8. & ResG & 104 & Tinggi & 19. & ResR & 104 & Tinggi \\
\hline 9. & ResH & 102 & Tinggi & 20. & ResS & 101 & Tinggi \\
\hline 10. & Resl & 102 & Tinggi & 21. & ResT & 100 & Tinggi \\
\hline 11. & ResJ & 104 & Tinggi & 22. & ResU & 103 & Tinggi \\
\hline
\end{tabular}

Berdasarkan perbandingan data kemampuan komunikasi interpersonal peserta didik kelas XI IPS di SMAN 7 Kota Kediri antara sebelum dan sesudah diberikan layanan bimbingan kelompok, dapat ditarik kesimpulan bahwa layanan bimbingan teman sebaya berpengaruh meningkatkan komunikasi interpersonal peserta didik. Dari 22 peserta didik yang memiliki kemampuan komunikasi interpersonal rendah, meningkat menjadi 2 peserta didik yang memiliki kemampuan komunikasi sedang dan 20 peserta didik yang memiliki kemampuan komunikasi interpersonal tinggi.

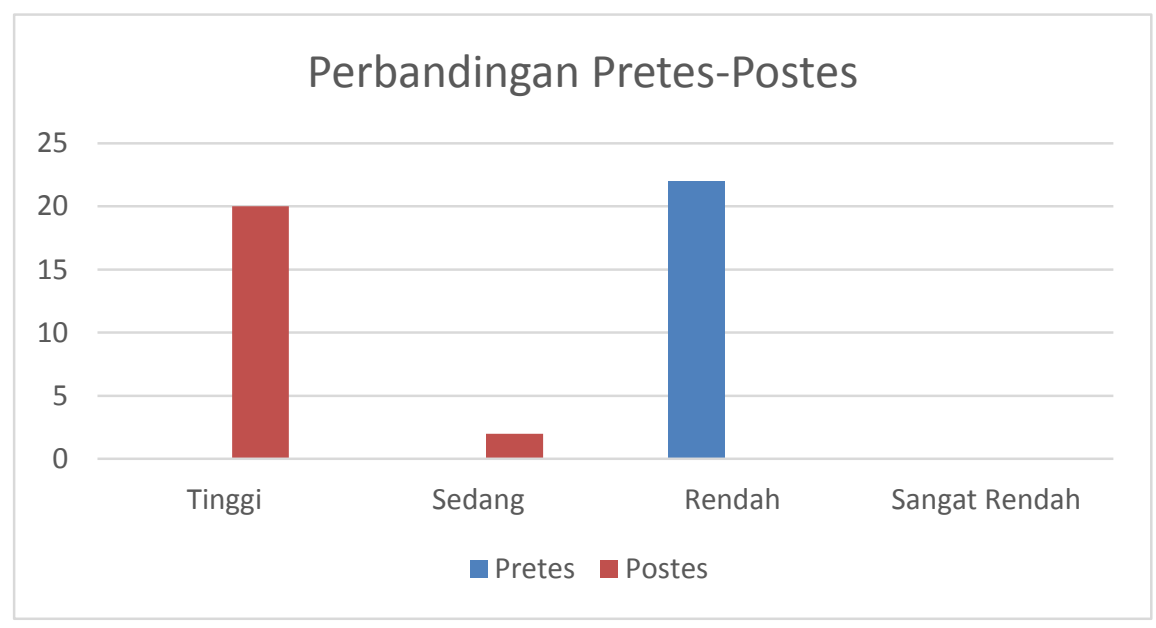

Grafik 1. Perbadingan Hasil Pretest dan Posttest 


\section{PEMBAHASAN}

Berisi diskusi atau tindakan peneliti dalam mengkritisi hasil penelitian sesuai teori atau karya ilmiah lainnya termasuk penelitian terdahulu. Hasil penelitian yang sudah diuraikan, dibahas satu per satu secara komprehensif.

Berdasarkan hasil analisis menunjukkan bahwa terdapat pengaruh komunikasi interpersonal pada peserta didik kelas XI IPS SMAN 7 Kediri setelah diberikan treatment dengan teknik bimbinganteman sebaya. Hal ini diketahuidari hasil postest masing-masing peserta didik yang mengikuti treatment ini berpengaruh dalam tingkatkomunikasi interpersonal dilihat dari pretest, selanjutnya dilakukan analisis data mengguakan SPSS 23.0 diperoleh nilai hasil thitung 34,799 dengan taraf signifikansi 0,05 sebesar 2,080. Hal ini membuktikan bahwa bimbingan teman sebaya berpengaruh terhadap komunikasi interpersonal peserta didik.

\section{KESIMPULAN DAN SARAN}

Berdasarkan hasil keseluruhan penelitian yang diperoleh dari pengumpulan data tentang pengaruh bimbingan teman sebaya terhadap komunikasi interpersonal peserta didik kelas XI IPS SMAN 7 Kota Kediri dapat disimpulkan bimbingan teman sebaya berpengaruh terhadap kemampuan komunikasi interpersonal peserta didik pada lima aspek yaitu keterbukaan, empati, dukungan, perilaku positif dan kesetaraan.

Bagi guru bimbingan dan konseling disarankan untuk model nimbingan teman sebaya ini dimasukan ke dalam satu program kerjanya disekolah dan diharapkan lebih memahami juga mampu mengimplementasikan layanan bimbingan teman sebaya disekolah yang terbukti memiliki pengaruh terhadao komunikasi interpersonal peserta didik.

Bagi peniliti selanjutnya, disarankan dapat mengusahakan untuk mengkaji masalah ini dengan jangkauan yang lebih luas terutama yang belum terungkap dalam penelitian ini dan dalam pelaksanaan treatment dengan menggunakan bimbingan teman sebaya, disarankan untuk lebih dari enam kali dan setiap selesai treatment perlu diberikan posttest supaya lebih terlihat perbedaannya.

\section{DAFTAR RUJUKAN}

Asosiasi Bimbingan dan Konseling Indonesia. 2007. Rambu-Rambu Penyelenggaraan Bimbingan dan Konseling dalam Jalur Pendidikan Formal. Jakarta: Dirjen PMPTK DIKNAS.

Astiningrum, Y. 2013. Bimbingan Teman Sebaya Untuk Meningkatkan Komunikasi Interpersonal Peserta didik. Artikel Jurnal. Yogyakarta : Universitas Sebelas Maret Surakarta.

Asmara, T. 2007. Efektifitas Bimbingan Kelompok Dengan Teknik Peer Group Dalam Meningkatkan Konsep Diri Peserta didik Kelas III A di SMP Mardipeserta didik 1 
Semarang Tahun Pelajaran 2006/2007. Skripsi. (online), Semarang : Universitas Negeri Semarang. diunduh 9 Oktober 2017.

Azwar, S. 2013. Penyusunan Skala Psikologi edisi 2. Yogyakarta : Pustaka Pelajar.

Arikunto, S. 2013. Prosedur Penelitian Suatu Pendekatan Klinik. Jakarta : Rineka Cipta.

Fajar, M. (2009). IImu Komunikasi Teori dan Praktek. Yogyakarta: Graha IImu.

Hanurawan, F. 2010. Psikologi Sosial. Bandung : Griya Sekar Terasi.

Iceu, R. 2011. Program Bimbingan Teman Sebaya Untuk Meningkatkan Percaya Diri Peserta didik. Jurnal Penelitian Pendidikan, Edisi Khusus, (1), 368-376. http//jurnal.upi.edu. diunduh 17 oktober 2017.

Mulyana, D. 2010. IImu Komunikasi. Bandung : PT. Remaja Rosdakarya.

Nurihsan, J.(2003). Proses Pembentukan Teman Sebaya Pada Remaja dan Etika Pergaulan Serta Dampaknya Terhadap Aspek Sosial Remaja. Makalah pada seminar remaja gaul dan perspektif psikologis di Auditorium FPMIPA UPI tanggal 18 Januari 2003.

Pramono, Dewi, Aulitunda. 2010. Pengaruh Teman Sebaya Terhadap Perilaku Seksual Sehat Remaja Di SMAN 8 Samarinda tahun 2010. Tersedia : htpp:/ejournal.com diunduh 13 agustus 2018.

Regina. Y. 2016. Pengaruh Komunikasi Interpersonal Guru Dan Pembelajaran Kontekstual Terhadap Komitmen Belajar Peserta didik Pada Mata Pelajaran Di Smpn 1 Raja Kabupaten Lampung Utara Tahun Pelajaran 2015/2016. Skripsi. Lampung: Universitas Lampung. 